\title{
ANALISIS KETIMPANGAN PEMBANGUNAN ANTARKABUPATEN/KOTA DI PROVINSI NUSA TENGGARA TIMUR TAHUN 2013-2017
}

\author{
(Analysis of Interregional Development Inequality in Nusa Tenggara Timur in 2013-2017)
}

\author{
Hendry Alfiansyah ${ }^{1}$, Budyanra ${ }^{2}$ \\ Politeknik Statistika STIS \\ Politeknik Statistika STIS \\ E-mail: alfiansyahhendry@gmail.com
}

\begin{abstract}
ABSTRAK
Pembangunan ekonomi merupakan upaya-upaya yang dilakukan negara untuk meningkatkan kesejahteraan masyarakat. Tujuan pembangunan ekonomi adalah untuk menciptakan pertumbuhan ekonomi dan perubahan struktur ekonomi, perubahan sosial, mengurangi atau menghapuskan kemiskinan, mengurangi ketimpangan, dan pengangguran. Namun tujuan itu masih belum tercapai di Indonesia, masih terjadi ketimpangan pembangunan antardaerah pada provinsi-provinsi di Indonesia yang dibuktikan melalui Indeks Williamson tahun 2013 hingga 2017, salah satunya terjadi di provinsi Nusa Tenggara Timur. Penelitian ini bertujuan untuk menganalisis gambaran umum ketimpangan pembangunan antarkabupaten/kota di Provinsi NTT serta menganalisis faktor-faktor yang memengaruhinya yang diukur dengan indeks Jaime Bonet. Metode yang digunakan adalah analisis deskriptif dan analisis regresi data panel. Hasil penelitian menunjukkan bahwa masih ada beberapa kabupaten/kota yang mengalami ketimpangan yang sangat tinggi. Analisis regresi data panel menunjukkan bahwa variabel angka melek huruf (AMH) dan dana alokasi umum (DAU) memiliki pengaruh yang negatif dan signifikan terhadap ketimpangan antardaerah, sedangkan variabel pendapatan asli daerah (PAD), belanja modal dan tingkat pengangguran terbuka (TPT) berpengaruh positif dan signifikan terhadap ketimpangan pembangunan antarkabupaten/kota di Provinsi NTT.
\end{abstract}

Kata kunci: ketimpangan antardaerah, indeks Jaime Bonet, regresi data panel

\begin{abstract}
Economic development is the efforts made by the state to improve people's welfare. Economic development goals are to create economic growth and change economic structures, social change, reduce or eliminate poverty, reduce inequality and unemployment. However, this goal has not yet been achieved in Indonesia, there are still regional development inequalities in provinces in Indonesia as evidenced by the Williamson Index in 2013 to 2017, one of which occurred in the province of East Nusa Tenggara. This study aims to analyze the general picture of development inequality between districts / cities in NTT Province and analyze the factors that influence it as measured by the Jaime Bonet index. The method used is descriptive analysis and panel data regression analysis. The results of the study show that there are still several districts/cities that experience very high inequality. Panel data regression analysis shows that the literacy rate $(A M H)$ and general allocation fund (DAU) variables have a negative and significant effect on inequality between regions, while the variable local revenue (PAD), capital expenditure and the open unemployment rate (TPT) are influential positive and significant impact on development inequality between districts / cities in NTT Province.
\end{abstract}

Keywords: interregional inequality, Jaime Bonet Index, panel data regression

\section{PENDAHULUAN}


Pembangunan ekonomi merupakan upaya-upaya yang dilakukan negara untuk meningkatkan kesejahteraan masyarakat. Menurut Todaro (2000), tujuan pembangunan ekonomi adalah untuk menciptakan pertumbuhan ekonomi dan perubahan struktur ekonomi, perubahan sosial, mengurangi atau menghapuskan kemiskinan, mengurangi ketimpangan, dan pengangguran. Ahliahli ekonomi klasik berpandangan bahwa ada empat faktor yang mempengaruhi pertumbuhan ekonomi, yaitu: jumlah penduduk, jumlah stok barang-barang modal, luas tanah dan kekayaan alam, serta teknologi yang digunakan. Walaupun menyadari bahwa pertumbuhan ekonomi tergantung pada banyak faktor, ahli-ahli ekonomi klasik terutama menitikberatkan perhatiannya kepada pengaruh pertambahan penduduk kepada pertumbuhan ekonomi (Sukirno, 2010).

Dalam prosesnya, ada beberapa masalah yang dapat muncul dalam pembangunan ekonomi, salah satunya adalah masalah ketimpangan distribusi pendapatan. Simon Kuznet (1955) mengatakan bahwa pada tahap awal, pertumbuhan ekonomi, distribusi pendapatan akan memburuk, namun pada tahap selanjutnya, distribusi pendapatannya akan mengalami peningkatan. Observasi inilah yang kemudian, dikenal sebagai kurva Kuznet "U-Terbalik", karena perubahan longitudinal (time-series) dalam distribusi pendapatan.

Masalah ketimpangan perlu segera diatasi karena ketimpangan yang ekstrim dapat mengakibatkan terjadinya inefisiensi ekonomi, melemahnya stabilitas sosial dan solidaritas, serta ketimpangan yang tinggi pada umumnya dipandang tidak adil (Todaro, 2004). Selain itu, adanya ketimpangan juga menunjukkan belum tercapainya salah satu tujuan berbangsa dan bernegara yaitu terwujudnya pemerataan pembangunan dan kesejahteraan untuk seluruh masyarakatnya.

Salah satu ukuran yang dapat digunakan untuk mengukur ketimpangan antar daerah adalah indeks Williamson. Indeks Williamson dapat menggambarkan ketimpangan yang terjadi antar daerah, berbeda dengan indeks Gini yang menjelaskan ketimpangan yang terjadi antargolongan pendapatan masyarakat. Nilai indeks Williamson berkisar antara nol dan satu. Indeks yang mendekati satu mengindikasikan ketimpangan antar wilayah yang semakin tinggi. Sebaliknya, indeks yang mendekati nol mengindikasikan ketimpangan antar wilayah yang semakin rendah (Sjafrizal, 2012).

Penelitian-penelitian sebelumnya yang menganalisis ketimpangan pembangunan dan faktorfaktor penyebabnya diantaranya adalah penelitian Nurhada, Muluk dan Prasetyo (2013) yaitu untuk mengetahui pengaruh variabel Produk Domestik Regional Bruto (PDRB), Pendapatan Asli Daerah (PAD), Dana Alokasi Umum (DAU), dan Indeks Pembangunan Manusia (IPM) terhadap ketimpangan pembangunan. Dari penelitian tersebut dihasilkan bahwa PAD dan IPM memiliki pengaruh negatif terhadap ketimpangan pembangunan. Sedangkan untuk PDRB dan DAU tidak berpengaruh secara signifikan.

Ariyanto (2017) menganalisis ketimpangan antarkabupaten/kota di Provinsi Jawa Tengah Tahun 2004-2013. Hasil penelitian menunjukkan bahwa berdasarkan analisis regresi data panel model FEM, faktor-faktor yang memengaruhi ketimpangan di Provinsi Jawa Tengah periode 20042013 adalah pertumbuhan ekonomi berpengaruh positif tetapi tidak signifikan, Indeks Pembangunan Manusia berpengaruh positif dan signifikan, Inflasi berpengaruh positif dan signifikan, tingkat kemiskinan berpengaruh negatif tetapi tidak signifikan, dan tingkat pengangguran terbuka berpengaruh negatif tetapi tidak signifikan.

Penelitian yang dilakukan oleh Andono (2011) menganalisis faktor penentu ketimpangan antar daerah di Indonesia periode 2007-2009. Hasil analisis menunjukkan bahwa pertumbuhan ekonomi dan $\mathrm{AMH}$ berpengaruh negatif dan signifikan terhadap tingkat ketimpangan. Sedangkan variabel pengangguran memiliki pengaruh positif dan signifikan terhadap ketimpangan antarwilayah.

Berdasarkan penjelasan masalah di atas dan penelitian-penelitian terdahulu, maka tujuan dari penelitian ini adalah menganalisis gambaran ketimpangan pembangunan antar kabupaten/kota di Provinsi Nusa Tenggara Timur tahun 2013 hingga 2017 dan menganalisis variabel-variabel yang memengaruhi terjadinya ketimpangan pembangunan antar kabupaten/kota di Provinsi Nusa Tenggara Timur tahun 2013 hingga 2017.

\section{METODE}


Variabel terikat yang pada penelitian ini adalah indeks ketimpangan pembangunan antar daerah (Indeks Jaime Bonet) yang dihitung menggunakan PDRB per kapita seperti penelitian yang dilakukan oleh Bonet (2006). Sedangkan variabel bebas yang diduga memengaruhi variabel terikat tersebut berdasarkan Sjafrizal (2012) antara lain Angka Melek Huruf (AMH), belanja modal, Dana Alokasi Umum (DAU), Pendapatan Asli Daerah (PAD), dan Tingkat Pengangguran Terbuka (TPT).

Rumusan indeks Jaime Bonet tersebut adalah sebagai berikut:

$$
I_{i t}=\left|\frac{P D R B C_{i t}}{P D R B C_{I t}}-1\right| \text {..... }
$$

Dimana:

$I_{i t} \quad=$ Indeks Jaime Bonet kabupaten/kota i tahun $\mathrm{t}$;

$P D R B C_{i t} \quad=$ PDRB per kapita kabupaten/kota i tahun $\mathrm{t}$;

$P D R B C_{I t} \quad=$ PDRB per kapita provinsi pada tahun $\mathrm{t}$.

Penelitian dilakukan pada 22 kabupaten/kota di Provinsi Nusa Tenggara Timur (NTT) dengan periode waktu mulai dari tahun 2013 hingga tahun 2017. Data dalam penelitian ini merupakan data sekunder yang diperoleh dari Badan Pusat Statistik (BPS). Data tersebut adalah data panel yang berupa cross section yang terdiri dari 22 kabupaten/kota di Provinsi NTT dan data time series selama 5 tahun dari tahun 2013 hingga tahun 2017, sehingga jumlah observasi yang digunakan adalah sebanyak 110 observasi.

Metode analisis yang digunakan dalam penelitian ini adalah analisis deskriptif dan analisis inferensia. Analisis deskriptif akan memberikan gambaran umum dari ketimpangan pembangunan antar daerah. Analisis inferensia yang digunakan adalah analisis regresi data panel. Metode ini digunakan untuk mengetahui pengaruh dari variabel $\mathrm{AMH}$, belanja modal, DAU, PAD, dan TPT terhadap variabel ketimpangan pembangunan antar daerah. Selain itu, metode ini juga digunakan untuk melakukan analisis dan menarik kesimpulan tentang besarnya pengaruh dari masing-masing variabel bebas terhadap variabel terikat tersebut. Model yang digunakan antara lain Common Effects Model, Fixed Effects Model, dan Random Effects Model.

Model Common Effects dirumuskan dalam Gujarati (2009) sebagai berikut:

$Y_{i t}=\alpha+\beta_{1} X_{1 i t}+\beta_{2} X_{2 i t}+\cdots+\beta_{k} X_{k i t}+u_{i t}$

Dimana:

$Y_{i t} \quad=$ Variabel terikat individu ke-i dan waktu ke-t;

$\alpha \quad=$ Intersep;

$\beta_{k} \quad=$ Slope variabel bebas ke-k;

$X_{\text {kit }} \quad=$ Variabel bebas-k individu ke-i dan waktu ke-t;

$u_{i t} \quad=$ Komponen error dari model.

Model Fixed Effects dalam Gujarati (2009) adalah sebagai berikut:

$Y_{i t}=\alpha_{i}+\beta_{1} X_{1 i t}+\beta_{2} X_{2 i t}+\cdots+\beta_{k} X_{k i t}+u_{i t}$

Dengan:

$\alpha_{i} \quad=\alpha+\mu_{i}$

Dimana:

$Y_{i t} \quad=$ Variabel terikat individu ke-i dan waktu ke-t;

$\alpha_{i} \quad=$ Intersep individu ke-i;

$\mu_{i} \quad=$ Efek individu ke-i;

$\beta_{k} \quad=$ Slope variabel bebas ke-k;

$X_{k i t}=$ Variabel bebas-k individu ke-i dan waktu ke-t;

$u_{i t} \quad=$ Komponen error dari model.

Model Random Effects dirumuskan dalam Gujarati (2009) sebagai berikut:

$Y_{i t}=\alpha+\beta_{1} X_{1 i t}+\beta_{2} X_{2 i t}+\cdots+\beta_{k} X_{k i t}+w_{i t}$

Dengan:

$w_{i t} \quad=u_{i t}+\mu_{i}$

Dimana:

$Y_{i t} \quad=$ Variabel terikat individu ke-i dan waktu ke-t;

$\alpha \quad=$ Intersep;

$\beta_{k} \quad=$ Slope variabel bebas ke-k;

$X_{k i t}=$ Variabel bebas-k individu ke-i dan waktu ke-t; 
$w_{i t} \quad=$ Komponen error gabungan;

$u_{i t} \quad=$ Komponen error dari model.

\section{HASIL DAN PEMBAHASAN}

Ketimpangan pembangunan antar kabupaten/kota di Nusa Tenggata Timur digambarkan menggunakan indeks Jaime Bonet yang mengukur ketimpangan antar daerah. Keadaan pemerataan sempurna terjadi saat PDRB per kapita di tingkat kabupaten/kota sama dengan PDRB per kapita di tingkat provinsi. Gambaran ketimpangan pembangunan antar kabupaten/kota di Provinsi Nusa Tenggara Timur ditunjukkan pada Gambar 1.

Kabupaten/kota dengan tingkat ketimpangan tertinggi setiap tahunnya selama periode tahun 2013 hingga 2017 adalah Kota Kupang. Nilai indeks ketimpangan Kota Kupang tergolong nilai ketimpangan pembangunan yang sangat tinggi karena nilainya melebihi satu. Hal ini terjadi karena tingkat Produk Domestik Bruto Regional (PDRB) per kapita di Kota Kupang yang jauh lebih tinggi daripada PDRB per kapita di tingkat provinsi. Sedangkan kabupaten/kota dengan nilai ketimpagan terrendah pada tahun 2013 hingga tahun 2017 secara berurutan adalah Kabupaten Timor Tengah Utara, Kabupaten Nagekeo, Kabupaten Alor, Kabupaten Manggarai, dan Kabupaten Manggarai kembali. Tingkat ketimpangan yang rendah mengindikasikan bahwa PDRB per kapita pada tingkat kabupaten/kota telah mendekati PDRB per kapita pada tingkat provinsi.

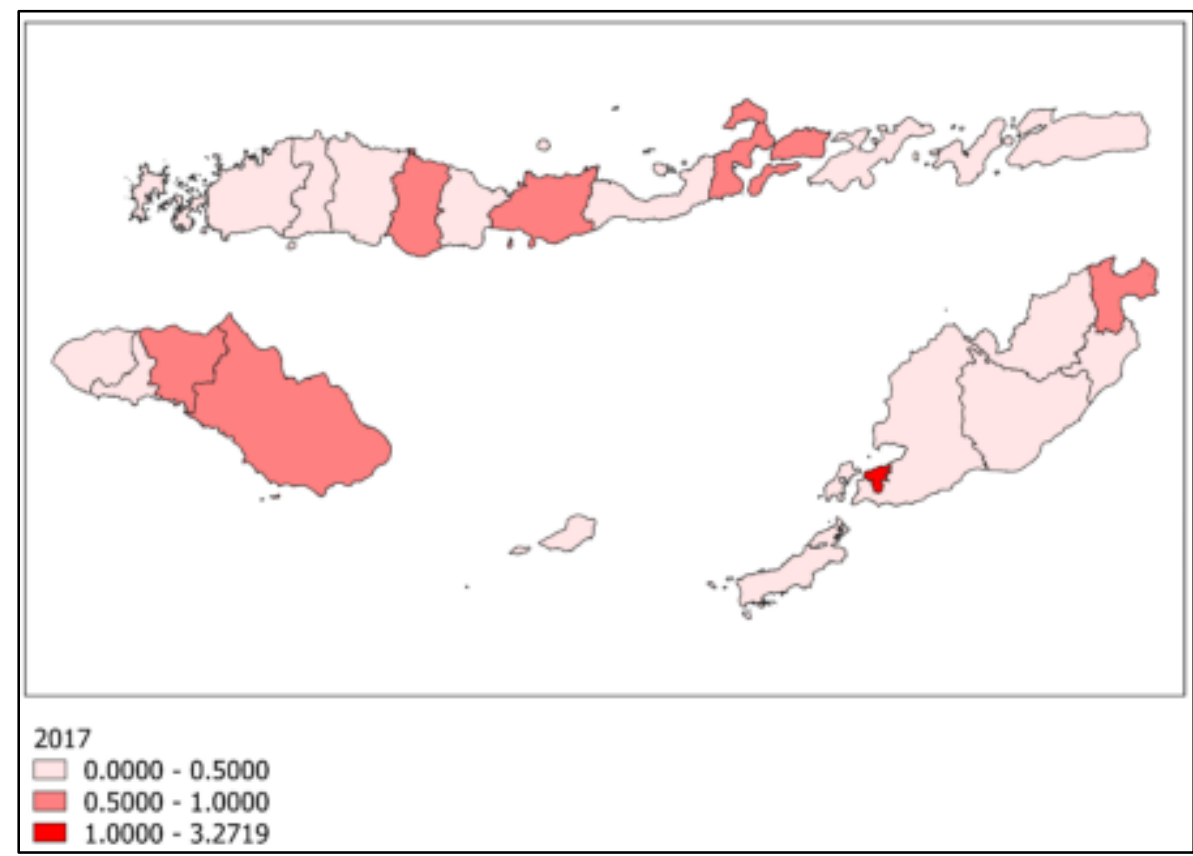

Gambar 1. Ketimpangan pembangunan antar kabupaten/kota di Provinsi Nusa Tenggara Timur tahun 2017.

Hasil analisis inferensia menunjukkan bahwa fixed effects model merupakan model terbaik dalam menjelaskan pengaruh variabel bebas terhadap variabel terikat sebagai berikut:

$$
\begin{gathered}
\widehat{I_{l t}}=\left(2.4843+\mu_{i}\right)-0,0172 A M H_{i t}+0,1353 \operatorname{LnBM}_{i t}-0,3318 \operatorname{LnDAU} U_{i t}+0,1986 \operatorname{LnPAD} D_{i t} \\
+0,0132 T P T_{i t}
\end{gathered}
$$

Dimana:

$\widehat{I_{l t}} \quad=$ Nilai Indeks Jaime Bonet kabupaten/kota i pada tahun $\mathrm{t}$;

$\mu_{i} \quad=$ Efek individu kabupaten/kota i;

$A M H_{i t} \quad=$ Angka Melek Huruf kabupaten/kota i pada tahun t;

$\operatorname{LnBM}_{i t} \quad$ = Logaritma natural belanja modal kabupaten/kota i pada tahun t;

$\operatorname{LnDAU}_{i t} \quad$ = Logaritma natural DAU kabupaten/kota i pada tahun t; 
$\operatorname{LnPAD}_{i t} \quad=$ Logaritma natural PAD kabupaten/kota i pada tahun $\mathrm{t}$; $T P T_{i t} \quad=$ Tingkat Pengagguran Terbuka kabupaten/kota i pada tahun t;

Pada tingkat signifikansi 5 persen, AMH berpengaruh secara signifikan terhadap ketimpangan pembangunan. Nilai sebesar -0,0172 menunjukkan hubungan yang negatif antara AMH dengan ketimpangan pembangunan, artinya jika $\mathrm{AMH}$ meningkat sebesar 1 persen, maka nilai ketimpangan pembangunan akan menurun sebesar 0,0172 poin dengan asumsi variabel lainnya konstan.

Belanja modal berpengaruh secara signifikan terhadap ketimpangan pembangunan. Nilai sebesar 0,1353 menunjukkan hubungan yang positif antara belanja modal dengan ketimpangan pembangunan, artinya jika belanja modal suatu daerah meningkat sebesar 1 persen, maka nilai ketimpangan pembangunan akan meningkat sebesar 0,1353 poin dengan asumsi variabel lainnya konstan.

DAU berpengaruh secara signifikan terhadap ketimpangan pembangunan. Nilai sebesar 0,3318 menunjukkan hubungan yang negatif antara DAU dengan ketimpangan pembangunan, artinya jika DAU suatu daerah meningkat sebesar 1 persen, maka nilai ketimpangan pembangunan akan menurun sebesar 0,3318 poin dengan asumsi variabel lainnya konstan.

PAD berpengaruh secara signifikan terhadap ketimpangan pembangunan. Nilai sebesar 0,1986 menunjukkan hubungan yang positif antara PAD dengan ketimpangan pembangunan, artinya jika PAD suatu daerah meningkat sebesar 1 persen, maka nilai ketimpangan pembangunan akan meningkat sebesar 0,1986 poin dengan asumsi variabel lainnya konstan.

TPT berpengaruh secara signifikan terhadap ketimpangan pembangunan. Nilai sebesar 0,0132 menunjukkan hubungan yang positif antara TPT dengan ketimpangan pembangunan, artinya jika TPT suatu daerah meningkat sebesar 1 persen, maka nilai ketimpangan pembangunan akan meningkat sebesar 0,0132 poin dengan asumsi variabel lainnya konstan.

\section{KESIMPULAN}

Berdasarkan hasil dan pembahasan penelitian pada bab sebelumnya, dapat diambil kesimpulan bahwa secara umum, rata-rata nilai ketimpangan pembangunan antar kabupaten/kota di Provinsi Nusa Tenggara Timur setiap tahunnya meningkat. Kabupaten/kota dengan nilai ketimpangan pembangunan antar daerah yang tertinggi setiap tahunnya selama periode observasi 2013 hingga 2017 adalah Kota Kupang, sedangkan kabupaten/kota dengan nilai ketimpagan rendah pada tahun 2013 hingga tahun 2017 secara berurutan adalah Kabupaten Timor Tengah Utara, Kabupaten Nagekeo, Kabupaten Alor, Kabupaten Manggarai, dan Kabupaten Manggarai kembali.

Dari hasil analisis regresi data panel, variabel Angka Melek Hurut (AMH), belanja modal, Dana Alokasi Umum (DAU), Pendapatan Asli Daerah (PAD) dan Tingkat Pengangguran Terbuka (TPT) berpengaruh signifikan terhadap ketimpangan pembangunan antarkabupaten/kota di Provinsi Nusa Tenggara Timur pada periode 2013-2017 baik secara simultan maupun parsial. Belanja modal, PAD dan TPT berpengaruh secara positif terhadap ketimpangan pembangunan, sedangkan AMH dan DAU berpengaruh negatif terhadap ketimpangan pembangunan.

\section{DAFTAR PUSTAKA}

\section{Artikel dalam Jurnal (Jurnal Primer)}

Nurhuda, Muluk dan Prasetyo. (2013). Analisis Ketimpangan Pembangunan (Studi Di Provinsi Jawa Timur Tahun 2005-2011). Jurnal Administrasi Publik (JAP), Vol. 1, Nomor 4, Hal. 110-119.

\section{Buku}

Bonet, Jaime. (2006). Fiscal Decentralization and Regional Income Disparities: Evidence from the Colombian Experience. Springer Verlag.

Gujarati, Damodar N., dan Dawn C.P. (2009). Basic Econometrics. Singapura: McGraw-Hill. 
Kuznets, Simon. (1955). "ECONOMIC GROWTH AND INCOME INEQUALITY*". The American Economic Review, VOLUME XLV MARCH, 1955 NUMBER ONE.

Sjafrizal. (2012). Ekonomi Wulayah dan Perkotaan, Jakarta: Rajawali Pers.

Sukirno, Sadono. (2010). Ekonomi Pembangunan: Proses, Masalah dan Dasar Kebijakan. Jakarta: Kencana. Todaro, Michael P. (2000). Pembangunan Ekonomi di Dunia Ketiga. Terjemahan, Edisi Kedelapan, Jilid 1 dan 2, Penerbit Erlangga, Jakarta.

Todaro, Michael P. dan Stephen C. Smith. (2004). Pembangunan Ekonomi di Dunia Ketiga, Edisi kedelapan. Jakarta : Erlangga.

\section{Skripsi/Tesis/Disertasi}

Andono, Ari Widi. (2011). Analisis Faktor Penentu dan Tingkat Ketimpangan Kemiskinan Antar Wilayah di Indonesia Periode 2007-2009. Surakarta: Universitas Sebelas Maret.

Ariyanto, Agung. (2017). Analisis ketimpangan antarkabupaten/kota di Provinsi Jawa Tengah Tahun 2004-2013. Yogyakarta: Universitas Gadjah Mada. 